\title{
Antibacterial Potential of Northeastern Portugal Wild Plant Extracts and Respective Phenolic Compounds
}

\author{
Eva Pinho, ${ }^{1,2}$ Isabel C. F. R. Ferreira, ${ }^{3}$ Lillian Barros, ${ }^{3}$ \\ Ana Maria Carvalho, ${ }^{3}$ Graça Soares, ${ }^{2}$ and Mariana Henriques ${ }^{1}$ \\ ${ }^{1}$ CEB, Centre for Biological Engineering, University of Minho, Campus Gualtar, 4710-057 Braga, Portugal \\ ${ }^{2}$ Centre for Textile Science and Technology (2C2T), University of Minho, Campus Azurém, 4800-058 Guimarães, Portugal \\ ${ }^{3}$ CIMO/School of Agriculture, Polytechnic Institute of Bragança, Campus de Santa Apolónia, 172, 5301-855 Bragança, Portugal \\ Correspondence should be addressed to Eva Pinho; evapinho@deb.uminho.pt
}

Received 6 February 2014; Revised 9 March 2014; Accepted 13 March 2014; Published 8 April 2014

Academic Editor: Adair Santos

Copyright (C) 2014 Eva Pinho et al. This is an open access article distributed under the Creative Commons Attribution License, which permits unrestricted use, distribution, and reproduction in any medium, provided the original work is properly cited.

\begin{abstract}
The present work aims to assess the antibacterial potential of phenolic extracts, recovered from plants obtained on the North East of Portugal, and of their phenolic compounds (ellagic, caffeic, and gallic acids, quercetin, kaempferol, and rutin), against bacteria commonly found on skin infections. The disk diffusion and the susceptibility assays were used to identify the most active extracts and phenolic compounds. The effect of selected phenolic compounds on animal cells was assessed by determination of cellular metabolic activity. Gallic acid had a higher activity, against gram-positive (S. epidermidis and S. aureus) and gram-negative bacteria (K. pneumoniae) at lower concentrations, than the other compounds. The caffeic acid, also, showed good antibacterial activity against the 3 bacteria used. The gallic acid was effective against the 3 bacteria without causing harm to the animal cells. Gallic and caffeic acid showed a promising applicability as antibacterial agents for the treatment of infected wounds.
\end{abstract}

\section{Introduction}

Skin, the largest human organ, works as a mechanical barrier against environment hazards and is, also, responsible for selfhealing, immune surveillance, sensor detection, thermoregulation, and fluid homeostasis $[1,2]$. Injuries, caused by extreme temperature, trauma, chronic ulcerations, pressure, or venous stasis, promote disruption of skin integrity allowing the deposition and colonisation of the injury tissue by a wide range of bacteria [3]. Skin and soft tissues infections are typically associated with staphylococci or streptococci, but virtually any microorganism may induce tissue inflammation and immune response $[4,5]$. The severity of these infections may range from self-limit superficial infections to lifethreatening diseases. The most common treatment is the use of broad-spectrum antibiotics. However, the indiscriminate use of this kind of drugs affects the normal skin flora and may result in multiresistant strains [6]. In order to overcome this issue it is critical to identify new antimicrobial agents.

Plants are a viable, unlimited source of bioactive molecules, including antimicrobial agents which protect them from microorganism, insects, and predators [7-11]. Phenolic compounds belong to these bioactive molecules' group; their pharmaceutical properties and benefits for human health have been demonstrated in several published studies [7, 8]. Anti-inflammatory, antioxidant, and antimicrobial are some of the properties attributed to those molecules $[7,8]$.

The northeastern region of Portugal, Trás-os-Montes, gathers a wide range of wild plants used on folk pharmacopeia and traditional cuisine. Several ethnobotanical surveys conducted in this region by Mountain Research Centre (CIMO)ESA, Polytechnic Institute of Bragança, selected some of these wild plants as potential source of natural antimicrobial agents.

The present work aims to select phenolic compounds identified on extracts of selected wild plants from northeastern region of Portugal to be applied as antibacterial agents on the treatment of infected wounds. The antibacterial activity of 8 phenolic extracts and 6 phenolic compounds was tested against Staphylococcus epidermidis, Staphylococcus aureus, and Klebsiella pneumoniae, usually associated with 
skin and soft tissue infections. The influence of the most effective phenolic compounds on human fibroblasts was, also, evaluated.

\section{Material and Methods}

2.1. Phenolic Extracts and Compounds. The plant samples and their phenolic extracts were obtained as described by Barros: Asparagus acutifolius (shoots), Aa, and Bryonia dioica (young stems), Bd [12]; Cytisus multiflorus (flowers), Cm, and Sambucus nigra (flowers), Sn, [13]; Rosa micrantha (flowers), $\mathrm{Rm}$, Filipendula ulmaria (inflorescences), $\mathrm{Fu}$, and Castanea sativa (upright catkins during anthesis), Cs [14]; and Cistus ladanifer (leaves), $\mathrm{Cl}$ [15]. The phenolic characterization of the extracts is also described on the publications mentioned above. Six different phenolic compounds, recovered from those plants, were pointed out as the main ones: 3 phenolic acids (caffeic, ellagic and gallic acids) and 3 flavonoids (kaempferol, quercetin and rutin) [12-15].

2.2. Strains and Growth Conditions. The antibacterial activity of the phenolic extracts and compounds was tested against 3 bacteria: Staphylococcus epidermidis (ATCC 12228), Staphylococcus aureus (ATCC 6538), and Klebsiella pneumoniae (ATCC 11296). The bacteria were grown in tryptic soy agar (TSA, Merck, Germany) for $24 \mathrm{~h}$ at $37^{\circ} \mathrm{C}$. The cells were inoculated in tryptic soy broth (TSB, Merck, Germany) and incubated for $18 \mathrm{~h}$ at $37^{\circ} \mathrm{C}$ under agitation $(120 \mathrm{rpm})$. Subsequently, bacterial concentration of each strain was adjusted to $1 \times 10^{6}$ cells $\cdot \mathrm{mL}^{-1}$, via absorbance readings and the corresponding calibration curve.

2.3. Disk Diffusion Assay. The antibacterial activity of the extracts or compounds against the 3 bacteria was assessed, first, by the disc diffusion method described by the National Committee for Clinical Laboratory Standards (NCCLS), M2A8 document [16], with some modifications. The TSA was the nutritive media used and it was prepared according to the instructions of the manufacturer. Afterwards, $200 \mu \mathrm{L}$ of each inoculum $\left(1 \times 10^{6}\right.$ cells $\left.\cdot \mathrm{mL}^{-1}\right)$ was spread on the solid media plates (90 mm Petri dishes). Sterile filter paper disks ("Blank Discs," Liofilchem, Roseto, Italy, $6 \mathrm{~mm}$ in diameter) were placed over the petri dish and impregnated with $20 \mu \mathrm{L}$ of each extract $\left(200 \mathrm{mg} \cdot \mathrm{mL}^{-1}\right)$ or compounds $\left(5 \mathrm{mg} \cdot \mathrm{mL}^{-1}\right)$. The plates were incubated at $37^{\circ} \mathrm{C}$ for $24 \mathrm{~h}$. Thereafter, the size of the halo from the inhibition growth was measured.

2.4. Susceptibility Assay: Minimal Inhibitory Concentration (MIC) and Minimal Bactericidal Concentration (MBC). MIC and $\mathrm{MBC}$ were obtained according to the method described by Wiegand et al. [17], an adaptation of the standard method published by Clinical and Laboratory Standards Institute (CLSI) and the European Committee on Antimicrobial Susceptibility Testing (EUCAST) [18], using the broth microdilution procedure. Thus, a work solution of $20 \mathrm{mg} \cdot \mathrm{mL}^{-1}$ of each extract and $10 \mathrm{mg} \cdot \mathrm{mL}^{-1}$ of each compound were prepared in sterile distilled water. The 96-well plate (Orange Scientific,
Braine-l' Alleud, Belgium) was prepared by adding $100 \mu \mathrm{L}$ of a solution of each extract/compound to a final concentration of $20 \mathrm{mg} \cdot \mathrm{mL}^{-1} / 10 \mathrm{mg} \cdot \mathrm{mL}^{-1}$ to the first well. Then serial dilutions (1:10) were made with MHB (Mueller-Hinton broth, Merck, Germany) in the other wells, to final volume of $50 \mu \mathrm{L}$. At each well, $50 \mu \mathrm{L}$ of each bacterium was added (S. epidermidis, $S$. aureus, and K. pneumoniae). The extracts concentration tested ranged between 0.02 and $10 \mathrm{mg} \cdot \mathrm{mL}^{-1}$ and the phenolic compounds from 0.01 to $5 \mathrm{mg} \cdot \mathrm{mL}^{-1}$. Drug-free and bacteria controls were also included. The plates were incubated for $24 \mathrm{~h}$ at $37^{\circ} \mathrm{C}$.

The MIC value was determined by the observation of the concentration that did not show any growth, by contrast with the bacteria control. The MBC, number of viable cells, was assessed by determination of the number of colony forming units (CFUs). The CFUs were measured by plating $10 \mu \mathrm{L}$ of cell suspension from each well onto TSA and incubated for $24 \mathrm{~h}$ at $37^{\circ} \mathrm{C}$.

The procedure was made in triplicate for each extract, compound and bacteria combination, in, at least, 3 independent assays.

2.5. Cytotoxicity Determination. Fibroblast 3T3 (CCL 163) from American Type Culture Collection was used in this study. Cells were cultured in Dulbecco's modified Eagle's medium (DMEM) supplemented with $10 \%$ of foetal bovine serum and $1 \%$ penicillin/streptomycin at $37^{\circ} \mathrm{C}, 5 \% \mathrm{CO}_{2}$. After achieving the confluence, cells were passed at the density of 1 $\times 10^{5}$ cells $\cdot \mathrm{mL}^{-1}$, using trypsin.

To assess the effect of the compounds on the cellular viability, the cells were seeded at the density of $5 \times 10^{5}$ cells $\cdot \mathrm{mL}^{-1}$ (24 well plate) in $1 \mathrm{~mL}$ of DMEM complete medium. After $24 \mathrm{~h}$, the medium was replaced by $500 \mu \mathrm{L}$ of fresh one and $500 \mu \mathrm{L}$ of compounds, at twofold of the desired concentrations dissolved in PBS. The plates were incubated for $24 \mathrm{~h}$ at $37^{\circ} \mathrm{C}$ and $5 \% \mathrm{CO}_{2}$. Afterwards, the medium was removed and a mixture of $20 \mu \mathrm{L}$ of MTS [3-(4,5-carboxymethoxyphenyl)2-(4-sulfophenyl)-2H-tetrazolium] (Promega) and $980 \mu \mathrm{L}$ of DMEM without phenol was added to each well. After $1 \mathrm{~h}$, the absorbance value was measured at $490 \mathrm{~nm}$ and the results were expressed as percentage of viable cells (\%), using the number of cells grown on wells without compounds as controls.

The procedure was made in triplicate for each compound, at least, in 3 independent assays.

\section{Results and Discussion}

The emergence of multiresistant strains of pathogenic and opportunistic bacteria is correlated with the widespread use of broad-spectrum antibiotics for treatment of skin and soft tissue infections. Therefore, the search for new drugs and new sources of antibacterial agents is of outmost importance [19]. Natural sources, such as plants, have been explored and gained prominence, since they offer many advantages when compared to the synthetic ones. For instance, they show high levels of biocompatibility and availability and low toxicity [710]. Currently, polyphenolics are the major group of interest 
in view of their anti-inflammatory, antimicrobial, antiviral, and antioxidant properties [20].

The antibacterial activity of phenolic extracts, from medicinal Portuguese plants, and, also, of polyphenolic compounds, identified on those extracts, was assessed by both qualitative and quantitative methods. The disk diffusion assay is a qualitative method, which allows a first screening of the potential antibacterial agents. However, this method presents some issues regarding the capacity of the active molecules to diffuse into the agar, and so, a quantitative method such as the MIC and MBC determination should be used in order to obtain more accurate results. The MIC is defined as the lowest concentration of the antibacterial agent that inhibits the visible bacteria growth observed with unaided eye, and the $\mathrm{MBC}$ is the minimal concentration of the antibacterial agent required to destroy most of the viable bacteria (reduction of 3 logs of growth) for a given set of conditions [21]. It is important to refer to the fact that the extracts and compounds present some colouration, which may lead to some misleading of the MIC values. Therefore, the MBC determination is crucial for a complementary analysis of the antibacterial properties of the phenolic extract/compounds [19].

3.1. Antimicrobial Activity of the Extracts. A preliminary assay using phenolic extracts of Portuguese medicinal plants was made, in order to identify phenolic compounds from those extracts. The chemical characterization of the phenolic extracts was described in previous works [12-15]. Both qualitative and quantitative analyses were made to the antibacterial activity of 8 phenolic extracts. From those extracts, only 5 (Cs, $\mathrm{Cl}, \mathrm{Cm}, \mathrm{Fu}$, and $\mathrm{Rm}$ ) were capable of reducing the growth of the 3 bacteria used (Figure 1). These extracts were selected as the most promising ones and their MIC and MBC values were assessed.

Thus, these extracts were selected as the most promising ones. As the disk diffusion assay is based on the measurement of the growth inhibition halo, which is dependent on the antibacterial agent ability to diffuse trough agar, quantitative complementary assays were also performed.

The MIC and MBC values revealed that the $\mathrm{Cs}$ and $\mathrm{Cl}$ had a similar effect on the bacteria, being more effective against $K$. pneumoniae and S. epidermidis (MIC and $\mathrm{MBC}$ $0.625 \mathrm{mg} \cdot \mathrm{mL}^{-1}$ (for both species)) and less effective against S. aureus (MIC 1.25 and $\mathrm{MBC} 2.5 \mathrm{mg} \cdot \mathrm{mL}^{-1}$ ). The $\mathrm{Fu}$ and $\mathrm{Rm}$ extracts, also, showed similar effect against the bacteria; namely, $2.5 \mathrm{mg} \cdot \mathrm{mL}^{-1}$ was capable of reducing completely the 3 bacteria growth when exposed to these 2 extracts. Since $\mathrm{Cm}$ phenolic extract had MIC and MBC values higher than $10 \mathrm{mg} \cdot \mathrm{mL}^{-1}$, this extract was not used for further analysis.

3.2. Antimicrobial Activity of the Phenolic Compounds. Six phenolic compounds identified in the extracts of $\mathrm{Cl}$ (ellagic acid, kaempferol, and gallic acid), Fu (caffeic acid, kaempferol, rutin, and gallic acid), Cs (gallic acid and rutin), and $\mathrm{Rm}$ (kaempferol) were selected for further analysis. Those compounds are all polyphenolics and can be placed into two groups: (1) phenolic acids and (2) flavonoids. Caffeic,

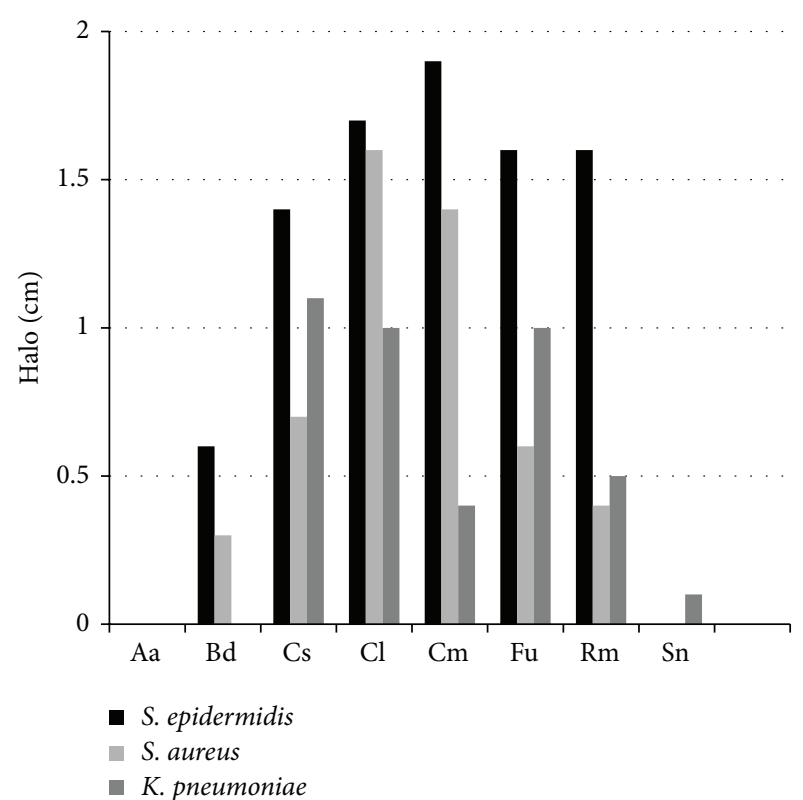

FIGURE 1: Values of the halo dimension (disk diffusion assay) for each extract $\left(200 \mathrm{mg} \cdot \mathrm{mL}^{-1}\right)$ for the 3 bacteria. The halo size was calculated by deducting the size of the disk $(0.6 \mathrm{~cm})$. Aa: $A$. acutifolius; Bd: B. dioica; CS: C. sativa; Cl: C. ladanife; Cm: C. multiflorus; Fu: F. ulmaria; Rm: R. Micrantha; and Sn: S. nigra.

gallic, and ellagic acid belong to the first group and the remaining compounds (kaempferol, quercetin, and rutin) fit into the flavonoids group.

The disk diffusion assay of the phenolic compounds (Figure 2) demonstrated that they can inhibit the growth of $S$. epidermidis, with the gallic acid being the most efficient and caffeic acid, rutin, and quercetin being the least efficient. The compounds present a similar halo size against $S$. aureus with the exception of ellagic acid that did not change the bacteria growth. Gallic acid and caffeic acid were the only phenolic compounds tested capable of inhibiting the Gram-negative bacteria (K. pneumoniae). Due to the different and interesting results of the compounds in the diffusion assay, it was decided to determine the MIC and MBC of all of them (Table 1).

Flavonoids are a group of polyphenolic molecules from plant source with many biological properties already studied $[22,23]$. The flavonoids antibacterial capacity is based on their ability to complex with extracellular and soluble proteins and to destroy the bacteria cell wall by interacting with essential enzymes responsible for maintaining the stability of this structure [7, 19]. However, in the conditions tested, the flavonoids selected (kaempferol, quercetin, and rutin) had no effect on the bacteria growth for concentrations under $5 \mathrm{mg} \cdot \mathrm{mL}^{-1}$.

Our results, similar to Penna's [24], suggest that kaempferol has no activity under $5 \mathrm{mg} \cdot \mathrm{mL}^{-1}$ against $S$. aureus. Additionally, Fattouch et al. [25] showed that kaempferol presented activity only at a concentration of $10 \mathrm{mg} \cdot \mathrm{mL}^{-1}$. Regarding quercetin antimicrobial activity, El-Gammal and Mansour [26] described that its MIC for S. aureus was $37 \mu \mathrm{g} \cdot \mathrm{mL}^{-1}$. Fattouch et al. [25] achieved a MIC 
TABLE 1: MIC and MBC of the selected compounds for each of the bacteria $\left(5 \times 10^{5}\right.$ cells $\left.\cdot \mathrm{mL}^{-1}\right)$.

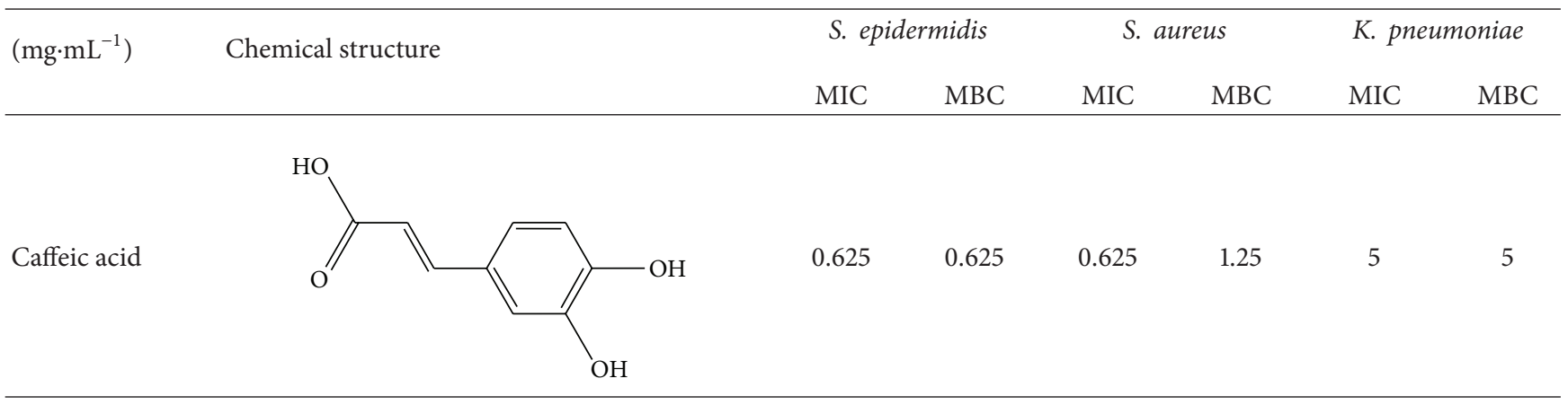
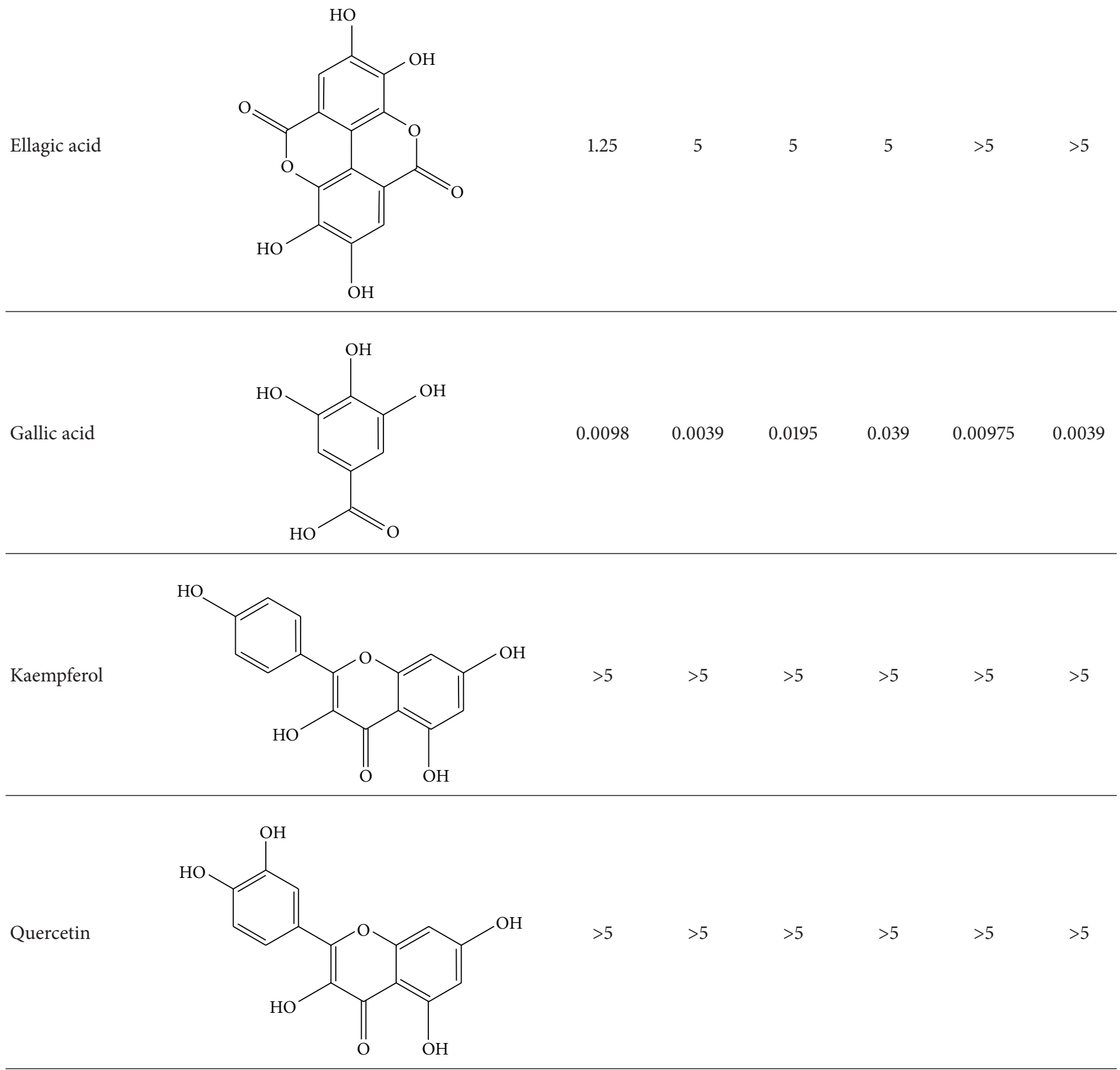
TABle 1: Continued.

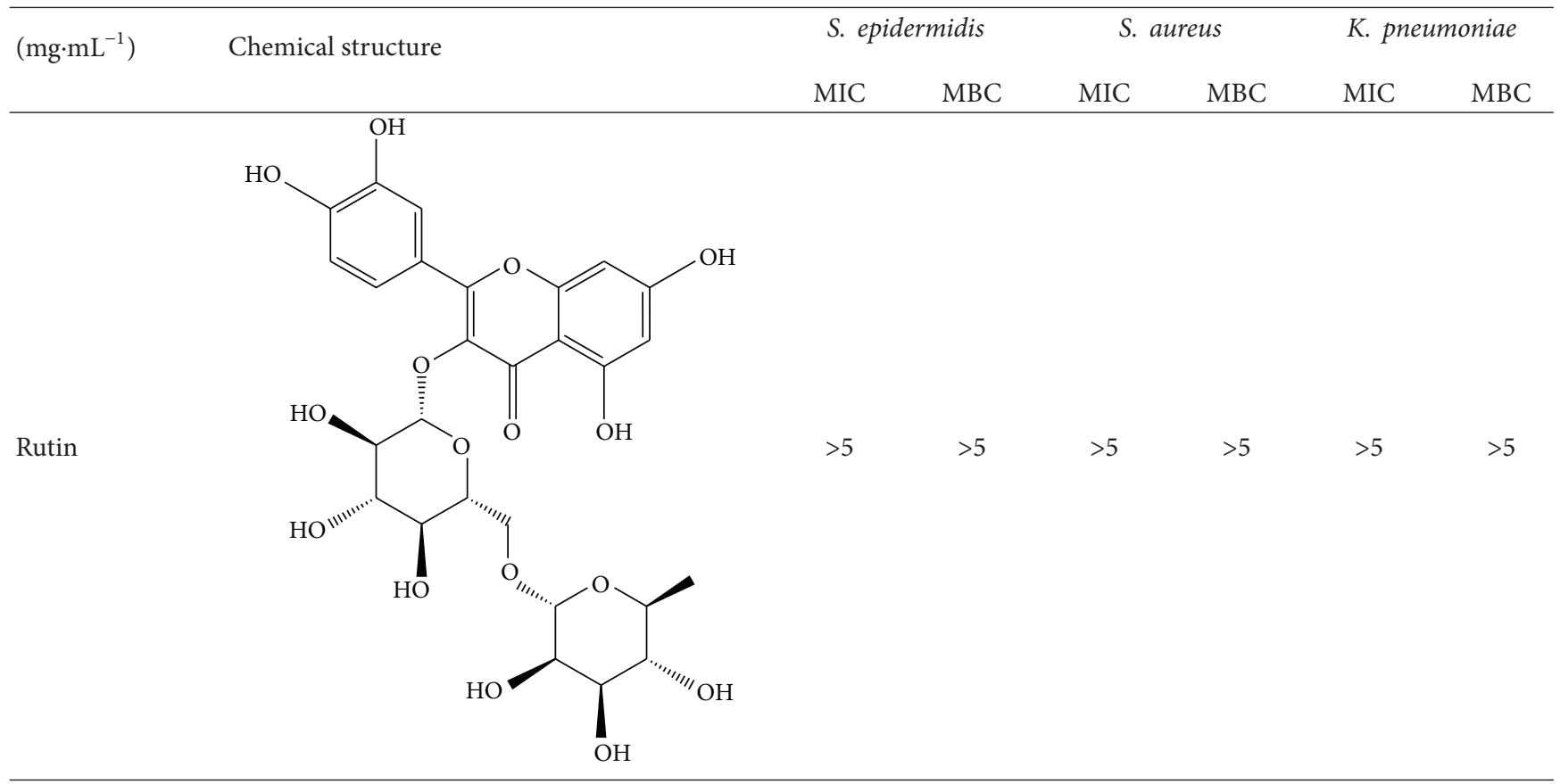

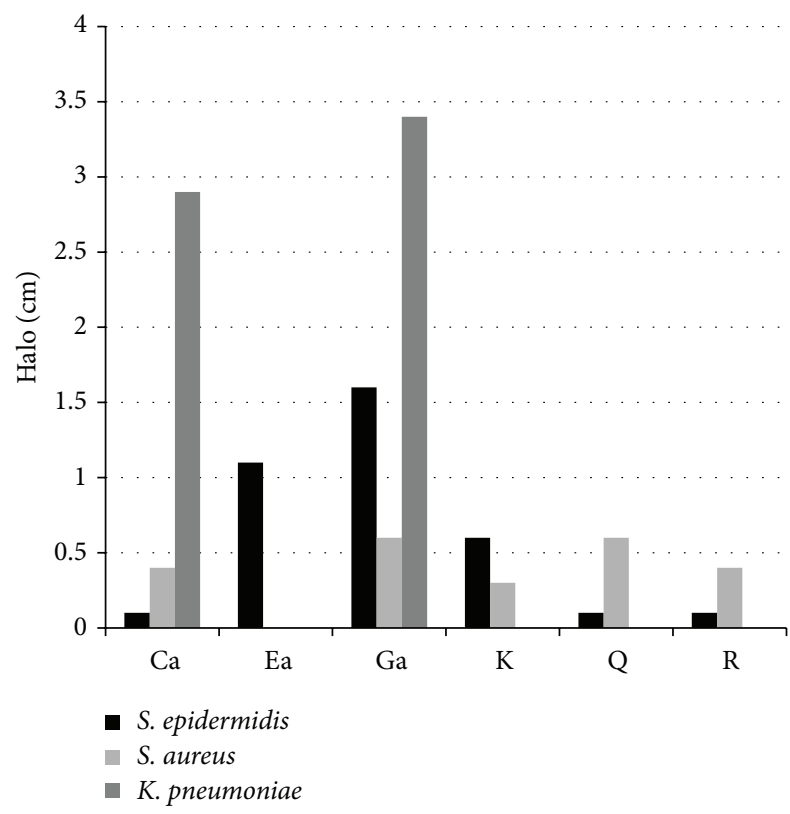

FIGURE 2: Values of the halo dimension (disk diffusion assay) for each extract $\left(5 \mathrm{mg} \cdot \mathrm{mL}^{-1}\right)$ for the 3 bacteria. The halo size was calculated by deducting the size of the disk $(0.6 \mathrm{~cm})$. Ca: caffeic acid; Ea: ellagic acid; Ga: gallic acid; K: kaempferol; Q: quercetin; and R: rutin.

and $\mathrm{MBC}$ for quercetin of $10 \mathrm{mg} \cdot \mathrm{mL}^{-1}$ for the same bacteria, which corroborates our results. In this case, the differences among results can be justified by the methods used. For instance, Fattouch et al. [25] used the microdilution method, the same procedure used in this work; however, El-Gammal and Mansour [26] used a method dependent on the diffusion capacity of the compounds which justify the differences on the MIC of the quercetin. In the case of rutin, some authors described that 0.5 or $4 \mathrm{mg} \cdot \mathrm{mL}^{-1}[27,28]$ was enough to destroy all cells of $S$. aureus, but our results suggest that rutin is not capable of reducing the total number of viable cells of $S$. aureus for concentrations under $5 \mathrm{mg} \cdot \mathrm{mL}^{-1}$. Bisignano et al. [27] obtained the MIC of rutin by the macrodilution method and, also, the phenolic compound was dissolved in DMSO; Orhan et al. [28] used the microdilution test, but they dissolved the rutin in ethanol-hexanol. In both situations, the MIC values described may be due to the solvents used for rutin dissolution and, also, the MBC should be assessed as a complementary method.

Concerning the phenolic acids tested, ellagic acid was not able to inhibit the growth of the 3 bacteria used, although its MIC for S. epidermidis was $1.25 \mathrm{mg} \cdot \mathrm{mL}^{-1}$. The ellagic acid has been described as antibacterial agent and its mechanism of action is related to the capacity to interact with enzymes, inhibiting their action and interactions with proteins [29]. Ohemeng et al. [30] showed that the MIC of the ellagic acid against the bacteria $S$. epidermidis and $S$. aureus was $0.125 \mathrm{mg} \cdot \mathrm{mL}^{-1}$ and Thiem and Goślińska [31], besides MIC, also determined the MCB of this phenolic acid against the same bacteria and reported the values of 0.63 and $2.5 \mathrm{mg} \cdot \mathrm{mL}^{-1}$, respectively.

In the literature, the gallic acid and the caffeic acid showed the same antibacterial mechanism, related to their similar structure (Table 1). These phenolic acids disrupted the bacteria cell by hyperacidification of the plasma membrane via proton donation and acidification of the intracellular cytosolic; this low $\mathrm{pH}$ can inhibit the enzyme $\mathrm{H}^{+}$-ATPase necessary for the ATP production [32-34]. Our results 
demonstrated that the gallic acid and the caffeic acid had effect against the 3 bacteria tested. However, the first phenolic was active against both Gram-positive and Gram-negative bacteria with concentration on the range of $\mu \mathrm{g} \cdot \mathrm{mL}^{-1}$ and the caffeic acid activity was only detected when concentrations between 0.625 and $5 \mathrm{mg} \cdot \mathrm{mL}^{-1}$ were used. Moreover, the $K$. pneumoniae was the most resilient bacteria to the caffeic acid (Table 1).

Most of the published works regarding the antibacterial activity of gallic and caffeic acids use the disk diffusion assay method without any quantitative analysis for complementary analysis [32, 35-37]. This which may lead to misleading results related to the capacity of these molecules to diffuse into the solid medium. Regarding the caffeic acid activity, Kwon et al. reported formation of halo when in contact with Gram-positive and Gram-negative bacteria for $50 \mathrm{mg} \cdot \mathrm{mL}^{-1}$ [32, 37]. Gutiérrez-Larraínzar et al. [35] obtained a MIC value for $S$. aureus of $561 \mu \mathrm{g} \cdot \mathrm{mL}^{-1}$ of gallic acid and Binutu and Cordell [38] had a MIC of $250 \mu \mathrm{g} \cdot \mathrm{mL}^{-1}, 10$ and 7 times higher, respectively, than the value attained in this work despite of the fact that method used was the same. The differences of the MIC value may rely on lower temperature $\left(35^{\circ} \mathrm{C}\right.$ instead of $\left.37^{\circ} \mathrm{C}\right)$ used for the growth of $S$. aureus by Gutiérrez-Larraínzar et al. [35] or in a misleading caused by the colouration of the gallic acid [19].

The differences found on the results published may be due to the diverse methods applied in each work to assess the MIC and MBC and/or interferences on the MIC and $\mathrm{MBC}$ procedure, such as variations on the volume and concentration inoculum, source of the flavonoid (natural or commercial), salts formation, and precipitation leading to misleading results [19].

\subsection{Effect of Gallic and Caffeic Acid on 3 T3 Fibroblast Growth} and Adhesion. Besides the antibacterial activity of natural molecules, the knowledge of their effect on the human cells is also crucial. Therefore, to predict the effects of the most promising phenolic compounds (gallic and caffeic acid) on animal cells, a preliminary assay of cytotoxicity was made.

The gallic acid showed no toxicity to the fibroblast when concentrations between 0.01 and $0.1 \mathrm{mg} \cdot \mathrm{mL}^{-1}$ were used (Figure 3(a)). In fact, the lowest concentration induced an increase on the number of viable cells measured. However, for concentrations above $0.1 \mathrm{mg} \cdot \mathrm{mL}^{-1}$, gallic acid became toxic.

The effect of caffeic acid on the viability of cells was dose dependent. The caffeic had no significant influence on the cells growth for concentrations between 0.06 and $1.26 \mathrm{mg} \cdot \mathrm{mL}^{-1}$, but a reduction greater than $30 \%$ of viability was measured when $6.31 \mathrm{mg} \cdot \mathrm{mL}^{-1}$, or higher, was applied.

Both phenolic compounds have been described as potent antioxidant, and as consequence they exert some chemopreventive effects on animal cells $[39,40]$. However, their antioxidant activity is based on oxidation-reduction reactions that are reversible and dependent on concentration. Therefore, these phenolics can act both as antioxidant and prooxidant, depending on the reaction conditions [39, 41]. This explains the fact that for higher concentrations gallic and caffeic acids induce major reduction on the cells

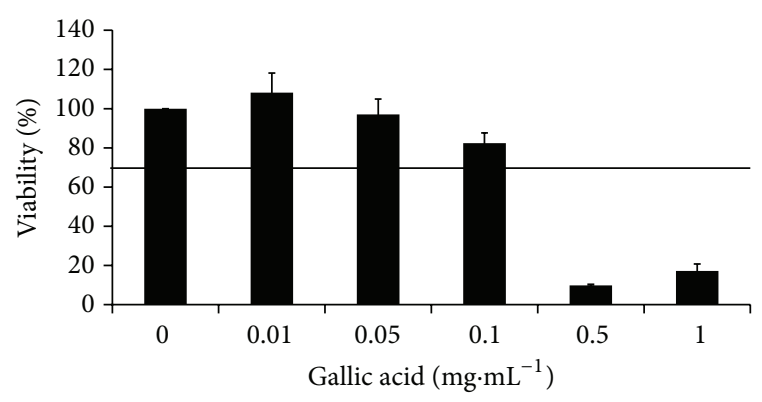

(a)

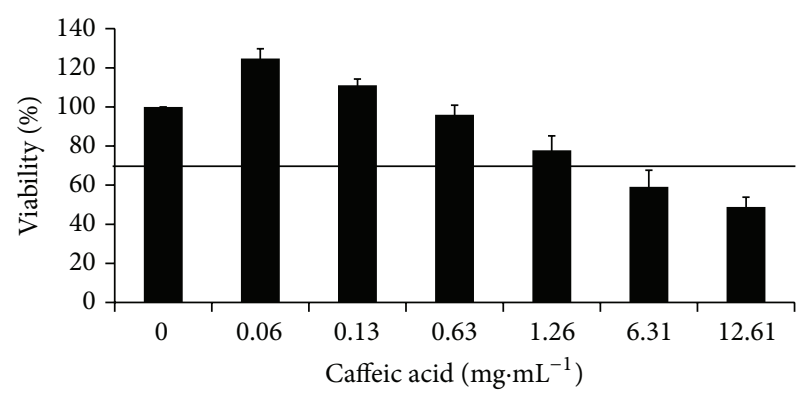

(b)

FIGURE 3: The viability of cells after $24 \mathrm{~h}$ of contact with gallic acid (a) and caffeic acid (b) dissolved in PBS, measured with an MTS assay. All data is expressed as mean + standard deviation $(n=9)$. The line indicates $70 \%$ of cell viability; when higher values were obtained the compound was considered nontoxic to the cells.

viability. Additionally, gallic acid was more toxic, since less than $20 \%$ of cells were capable of surviving for the concentrations between 0.5 and $1 \mathrm{mg} \cdot \mathrm{mL}^{-1}$ (Figure $3(\mathrm{a})$ ). For the same range of the concentrations, the cells tolerated the caffeic acid (Figure 3(b)). Our findings corroborate the fact that the predisposition to act as prooxidant is directly proportional to the number of hydroxyl groups in the molecule; gallic acid has 4 hydroxyl groups and caffeic only 3 (Table 1).

Nerveless, the gallic acid can be used as antibacterial agent against the bacteria tested without causing any damage to the animal cells, since its $\mathrm{MBC}$ was $0.04 \mathrm{mg} \cdot \mathrm{mL}^{-1}$ and at this range of concentrations the percentage of viable cells measured was higher than 70\%; above this limit the compounds are safe for humans based on the ISO 109935:2006. In the case of caffeic acid, the concentration capable of destroying all the bacteria was, also, toxic to the fibroblast, which may suggest that the mechanism involved on the antibacterial action is the same as one that causes damage to animal cells.

\section{Conclusion}

The results presented in this work highlight the potential of phenolic extracts from wild northeast Portuguese plants as antibacterial agents, as well as some of their phenolic compounds. 
Overall, extracts from Cistus ladanifer, Cytisus multiflorus, Castanea sativa, Filipendula ulmaria, and Rosa micrantha were capable of inhibiting the growth of the 3 bacteria commonly isolated from skin and soft tissue infections. Moreover, Cistus ladanifer, Castanea sativa, Filipendula ulmaria, and Rosa micrantha revealed promising antibacterial effects against $K$. pneumoniae, S. epidermidis, and $S$. aureus, in concentrations between 0.625 and $2.5 \mathrm{mg} \cdot \mathrm{mL}^{-1}$.

From those extracts, 6 phenolic compounds were selected. The flavonoids (kaempferol, quercetin, and rutin) were capable of inducing halo formation on Gram-positive bacteria. However, the quantitative assay of the flavonoids demonstrated that they were not active for concentrations below $5 \mathrm{mg} \cdot \mathrm{mL}^{-1}$. Regarding the phenolic acids, the ellagic acid was only active against $S$. epidermidis, but gallic and caffeic acids showed good antibacterial activity against the 3 bacteria at low concentrations. Thus, their effect on fibroblast proliferation was assessed and revealed that caffeic acid has dose-response cytotoxicity and can be considered safe for concentrations less than $6.31 \mathrm{mg} \cdot \mathrm{mL}^{-1}$. Regarding gallic acid, at the lowest concentration it promoted the proliferation of fibroblast but for concentrations above $0.1 \mathrm{mg} \cdot \mathrm{mL}^{-1}$ it became toxic. Nevertheless, conjugating the antibacterial and cytotoxicity results, it could be pointed out that gallic acid can be used safely presenting antibacterial activity against the 3 bacteria.

Therefore, the present work pretends to be a starting point to the use of phenolic compounds from northeastern Portugal plants on the treatment of infected wounds, instead of large-spectrum antibiotics.

\section{Conflict of Interests}

The authors have declared no conflict of interests.

\section{Acknowledgments}

The authors thank the Foundation for Science and Technology (Portugal) for financial support by the E. Pinho grant (SFRH/BD/62665/2009) and L. Barros grant (SFRH/BPD/ $4609 / 2000$ ), and by the projects PEst-OE/EQB/LA0023/2013, PEst-C/CTM/UI0264/2011, and PEst-OE/EQB/LA0023/ 2013. Also, the authors acknowledge the financial support from FEDER through Programa Operacional Factores de Competitividade-COMPETE and to COMPETE/QREN/EU (CIMO strategic project 19 PEst-OE/AGR/UI0690/2011), and through the Project "BioHealth-Biotechnology and Bioengineering approaches to improve health quality", Ref. NORTE-07-0124-FEDER-000027, co-funded by the Programa Operacional Regional do Norte (ON.2-O Novo Norte), QREN, FEDER. The authors also acknowledge the project "Consolidating Research Expertise and Resources on Cellular and Molecular Biotechnology at CEB/IBB", Ref. FCOMP-01-0124-FEDER-027462.

\section{References}

[1] A. D. Metcalfe and M. W. J. Ferguson, "Molecular and cellular basis of regeneration and tissue repair: skin stem and progenitor cells: using regeneration as a tissue-engineering strategy," Cellular and Molecular Life Sciences, vol. 65, no. 1, pp. 24-32, 2008.

[2] N. Boucard, C. Viton, D. Agay et al., "The use of physical hydrogels of chitosan for skin regeneration following thirddegree burns," Biomaterials, vol. 28, no. 24, pp. 3478-3488, 2007.

[3] A. M. Reitsma and G. T. Rodeheaver, Effectiveness of a New Antimicrobial Gauze Dressing as a Bacterial Barrier, 2007.

[4] M. J. DiNubile and B. A. Lipsky, "Complicated infections of skin and skin structures: when the infection is more than skip deep," Journal of Antimicrobial Chemotherapy, vol. 53, no. 2, pp. ii37ii50, 2004.

[5] B. A. Lipsky and C. Hoey, "Topical antimicrobial therapy for treating chronic wounds," Clinical Infectious Diseases, vol. 49, no. 10, pp. 1541-1549, 2009.

[6] M. S. Dryden, "Skin and soft tissue infection: microbiology and epidemiology," International Journal of Antimicrobial Agents, vol. 34, supplement 1, pp. S2-S7, 2009.

[7] M. M. M. Cowan, "Plant products as antimicrobial agents," Clinical Microbiology Reviews, vol. 12, no. 4, pp. 564-582, 1999.

[8] B. C. Aridoğan, H. Baydar, S. Kaya, M. Demirci, D. Özbaşar, and E. Mumcu, "Antimicrobial activity and chemical composition of some essential oils," Archives of Pharmacal Research, vol. 25, no. 6, pp. 860-864, 2002.

[9] R. Stojanovic, A. Belscak-Cvitanovic, V. Manojlovic, D. Komes, V. Nedovic, and B. Bugarski, "Encapsulation of thyme (Thymus serpyllum L.) aqueous extract in calcium alginate beads," Journal of the Science of Food and Agriculture, vol. 92, no. 3, pp. 685-696, 2012.

[10] J. Gou, Y. Zou, and J. Ahn, "Enhancement of antioxidant and antimicrobial activities of Dianthus superbus, Polygonum aviculare, Sophora flavescens, and Lygodium japonicum by pressureassisted water extraction," Food Science and Biotechnology, vol. 20, no. 1, pp. 283-287, 2011.

[11] E. P. Çoban, H. Biyik, and C. Uzun, "Investigation of antimicrobial activity of some natural plants which are not- cultivated and are sold at bazaars in aydin vicinity," International Journal of Engineering Science, vol. 3, pp. 59-62, 2009.

[12] L. Barros, M. Dueñas, I. C. F. R. Ferreira, A. Maria Carvalho, and C. Santos-Buelga, "Use of HPLC-DAD-ESI/MS to profile phenolic compounds in edible wild greens from Portugal," Food Chemistry, vol. 127, no. 1, pp. 169-173, 2011.

[13] L. Barros, M. Dueñas, A. M. Carvalho, I. C. F. R. Ferreira, and C. Santos-Buelga, "Characterization of phenolic compounds in flowers of wild medicinal plants from Northeastern Portugal," Food and Chemical Toxicology, vol. 50, no. 5, pp. 1576-1582, 2012.

[14] L. Barros, C. T. Alves, M. Dueñas et al., "Characterization of phenolic compounds in wild medicinal flowers from Portugal by HPLC-DAD-ESI/MS and evaluation of antifungal properties," Industrial Crops and Products, vol. 44, pp. 104-110, 2013.

[15] L. Barros, M. Dueñas, C. T. Alves et al., "Antifungal activity and detailed chemical characterization of Cistus ladanifer phenolic extracts," Industrial Crops and Products, vol. 41, pp. 41-45, 2012.

[16] M2-A8: Padronização dos Testes de Sensibilidade a Antimicrobianos por Disco-difusão: Norma Aprovada, 2005.

[17] I. Wiegand, K. Hilpert, and R. E. W. Hancock, "Agar and broth dilution methods to determine the minimal inhibitory concentration (MIC) of antimicrobial substances," Nature Protocols, vol. 3, no. 2, pp. 163-175, 2008.

[18] L. Nad and A. Agents, "Determination of minimum inhibitory concentrations (MICs) of antibacterial agents by agar dilution," Clinical Microbiology and Infection, vol. 6, no. 9, pp. 509-515, 2000 . 
[19] T. P. T. Cushnie and A. J. Lamb, "Antimicrobial activity of flavonoids," International Journal of Antimicrobial Agents, vol. 26, no. 5, pp. 343-356, 2005.

[20] E. Pinho, M. Grootveld, G. Soares, and M. Henriques, "Cyclodextrins as encapsulation agents for plant bioactive compounds," Carbohydrate Polymers, vol. 101, pp. 121-113, 2014.

[21] A. Barry, W. Craig, H. Nadler, and L. Reller :, Methods for Determining Bactericidal Activity of Antimicrobial Agents: Approved Guideline, 1999.

[22] B. H. Havsteen, "The biochemistry and medical significance of the flavonoids," Pharmacology and Therapeutics, vol. 96, no. 2-3, pp. 67-202, 2002.

[23] C. Hearst, G. Mccollum, D. Nelson et al., "Antibacterial activity of elder (Sambucus nigra L.) flower or berry against hospital pathogens," Journal of Medicinal Plant Research, vol. 4, no. 17, pp. 1805-1809, 2010.

[24] C. Penna, S. Marino, E. Vivot et al., "Antimicrobial activity of Argentine plants used in the treatment of infectious diseases. Isolation of active compounds from Sebastiania brasiliensis," Journal of Ethnopharmacology, vol. 77, no. 1, pp. 37-40, 2001.

[25] S. Fattouch, P. Caboni, V. Coroneo et al., "Antimicrobial activity of tunisian quince (Cydonia oblonga Miller) pulp and peel polyphenols extracts," Journal of Agricultural and Food Chemistry, vol. 55, no. 3, pp. 963-969, 2007.

[26] A. A. El-Gammal and R. M. Mansour, "Antimicrobial activities of some flavonoid compounds," Zentralblatt fur Mikrobiologie, vol. 141, no. 7, pp. 561-565, 1986.

[27] G. Bisignano, R. Sanogo, A. Marino et al., "Antimicrobial activity of Mitracarpus scaber extract and isolated constituents," Letters in Applied Microbiology, vol. 30, no. 2, pp. 105-108, 2000.

[28] D. D. Orhan, B. Özçelik, S. Özgen, and F. Ergun, "Antibacterial, antifungal, and antiviral activities of some flavonoids," Microbiological Research, vol. 165, no. 6, pp. 496-504, 2010.

[29] A. Munin and F. Edwards-Lévy, "Encapsulation of natural polyphenolic compounds; a review," Pharmaceutics, vol. 3, no. 4, pp. 793-829, 2011.

[30] K. A. Ohemeng, C. F. Schwender, K. P. Fu, and J. F. Barrett, "DNA gyrase inhibitory and antibacterial activity of some flavones," Bioorganic and Medicinal Chemistry Letters, vol. 3, no. 2, pp. 225-230, 1993.

[31] B. Thiem and O. Goślińska, "Antimicrobial activity of Rubus chamaemorus leaves," Fitoterapia, vol. 75, no. 1, pp. 93-95, 2004.

[32] Y.-I. Kwon, E. Apostolidis, R. G. Labbe, and K. Shetty, "Inhibition of Staphylococcus aureus by phenolic phytochemicals of selected clonal herbs species of Lamiaceae family and likely mode of action through proline oxidation," Food Biotechnology, vol. 21, no. 1, pp. 71-89, 2007.

[33] Y. T. Lin, Y. I. Kwon, R. G. Labbe, and K. Shetty, "Inhibition of Helicobacter pylori and associated urease by oregano and cranberry phytochemical synergies," Applied and Environmental Microbiology, vol. 71, no. 12, pp. 8558-8564, 2005.

[34] M. J. R. Vaquero, M. R. Alberto, and M. C. M. de Nadra, "Antibacterial effect of phenolic compounds from different wines," Food Control, vol. 18, no. 2, pp. 93-101, 2007.

[35] M. Gutiérrez-Larraínzar, J. Rúa, I. Caro et al., "Evaluation of antimicrobial and antioxidant activities of natural phenolic compounds against foodborne pathogens and spoilage bacteria," Food Control, vol. 26, no. 2, pp. 555-563, 2012.

[36] L. Panizzi, C. Caponi, S. Catalano, P. L. Cioni, and I. Morelli, "In vitro antimicrobial activity of extracts and isolated constituents of Rubus ulmifolius," Journal of Ethnopharmacology, vol. 79, no. 2, pp. 165-168, 2002.
[37] V. M. J. Rodríguez, P. A. A. Fernández, M. C. M. Nadra, and A. M. S. de Saad, "Phenolic compound combinations on Escherichia coli viability in a meat system," Journal of Agricultural and Food Chemistr, vol. 58, pp. 6048-6052, 2010.

[38] O. A. Binutu and G. A. Cordell, "Gallic acid derivatives from Mezoneuron benthamianum leaves," Pharmaceutical Biology, vol. 38, no. 4, pp. 284-286, 2000.

[39] J. H. Kim, N. J. Kang, B. K. Lee, K. W. Lee, and H. J. Lee, “Gallic acid, a metabolite of the antioxidant propyl gallate, inhibits gap junctional intercellular communication via phosphorylation of connexin 43 and extracellular-signal-regulated kinase1/2 in rat liver epithelial cells," Mutation Research, vol. 638, no. 1-2, pp. 175-183, 2008.

[40] C. Manach, G. Williamson, C. Morand, A. Scalbert, and C. Rémésy, "Bioavailability and bioefficacy of polyphenols in humans. I. Review of 97 bioavailability studies," The American Journal of Clinical Nutrition, vol. 81, no. 1, supplement, pp. 230242, 2005.

[41] Z. Lu, G. Nie, P. S. Belton, H. Tang, and B. Zhao, "Structureactivity relationship analysis of antioxidant ability and neuroprotective effect of gallic acid derivatives," Neurochemistry International, vol. 48, no. 4, pp. 263-274, 2006. 

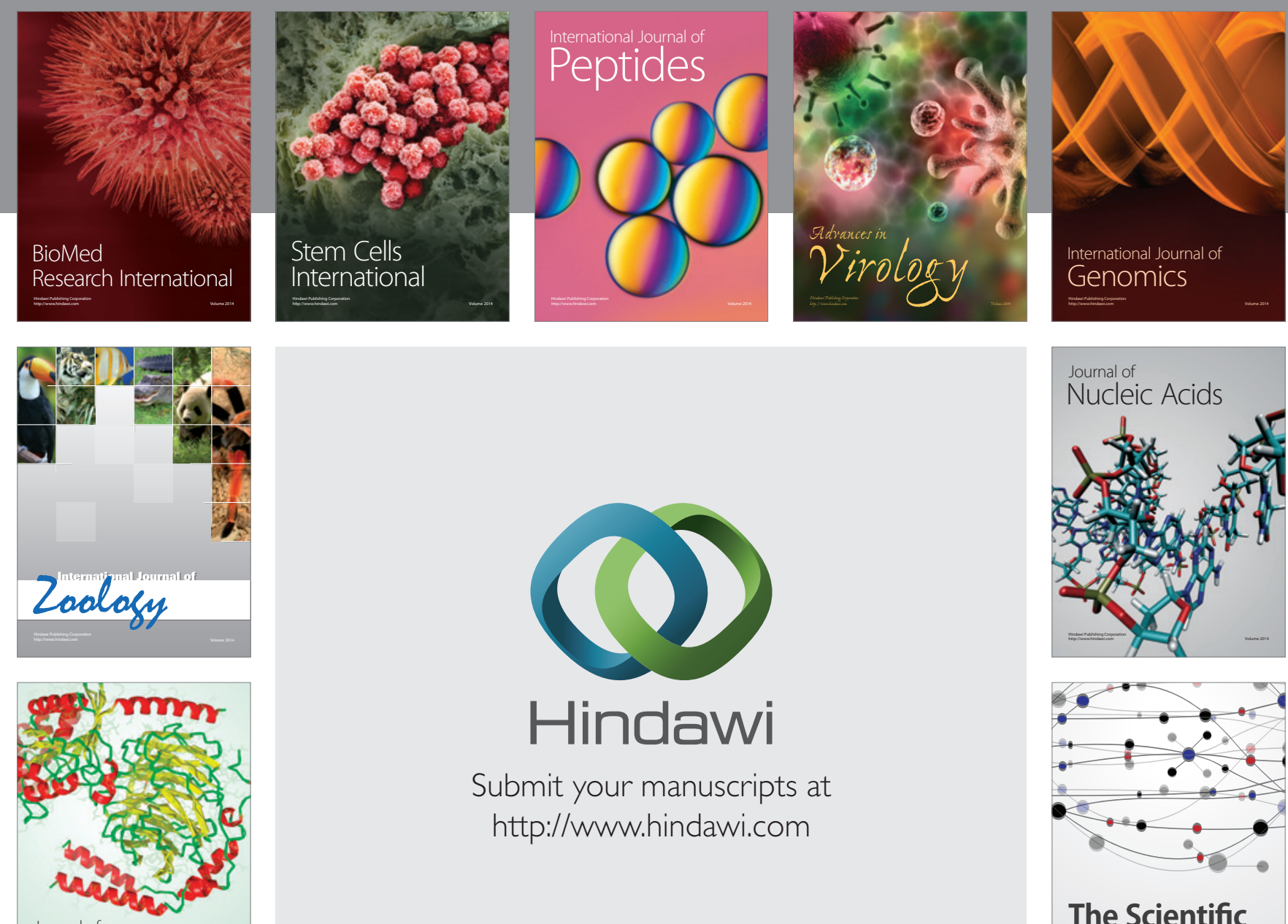

Submit your manuscripts at

http://www.hindawi.com

Journal of
Signal Transduction
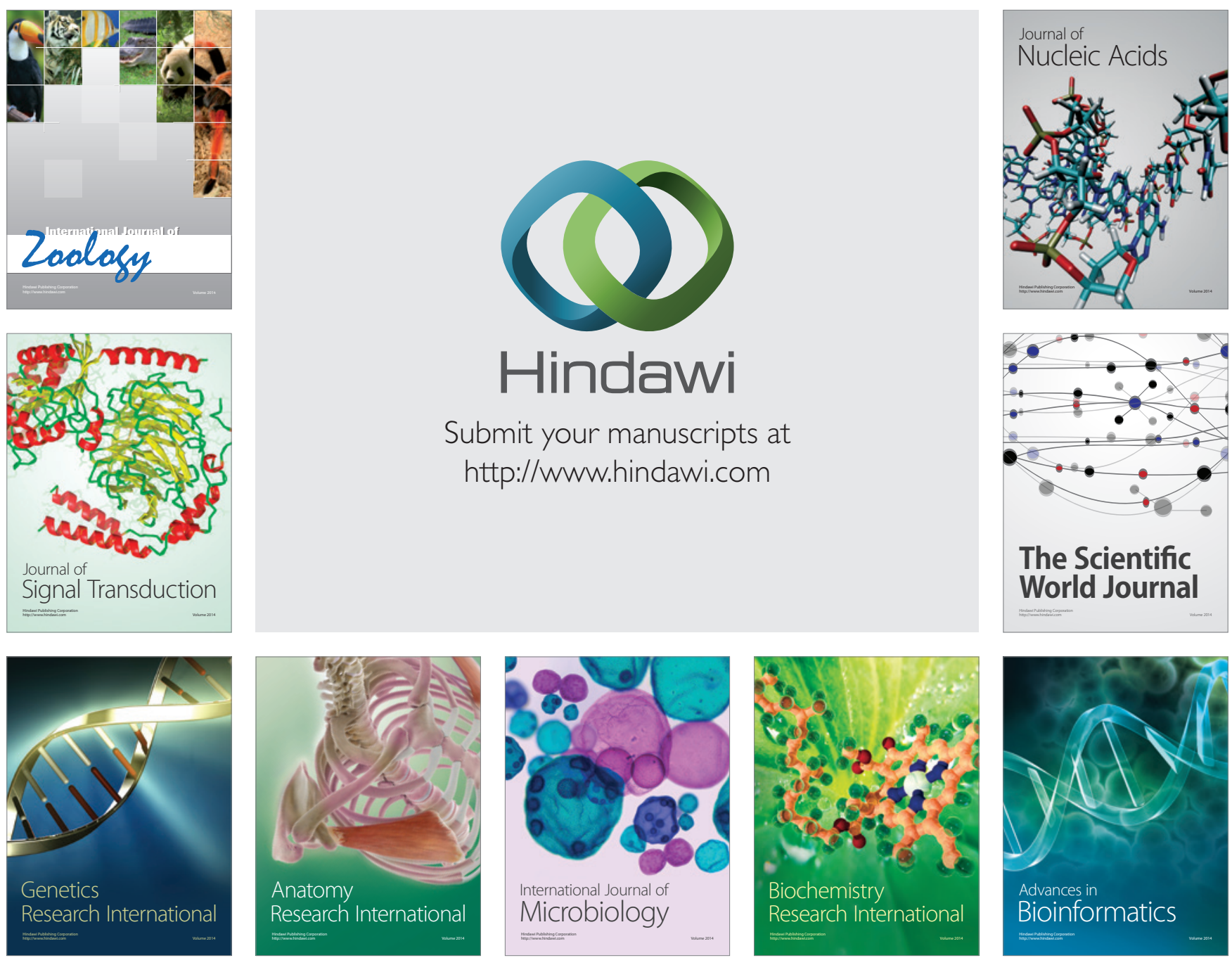

The Scientific World Journal
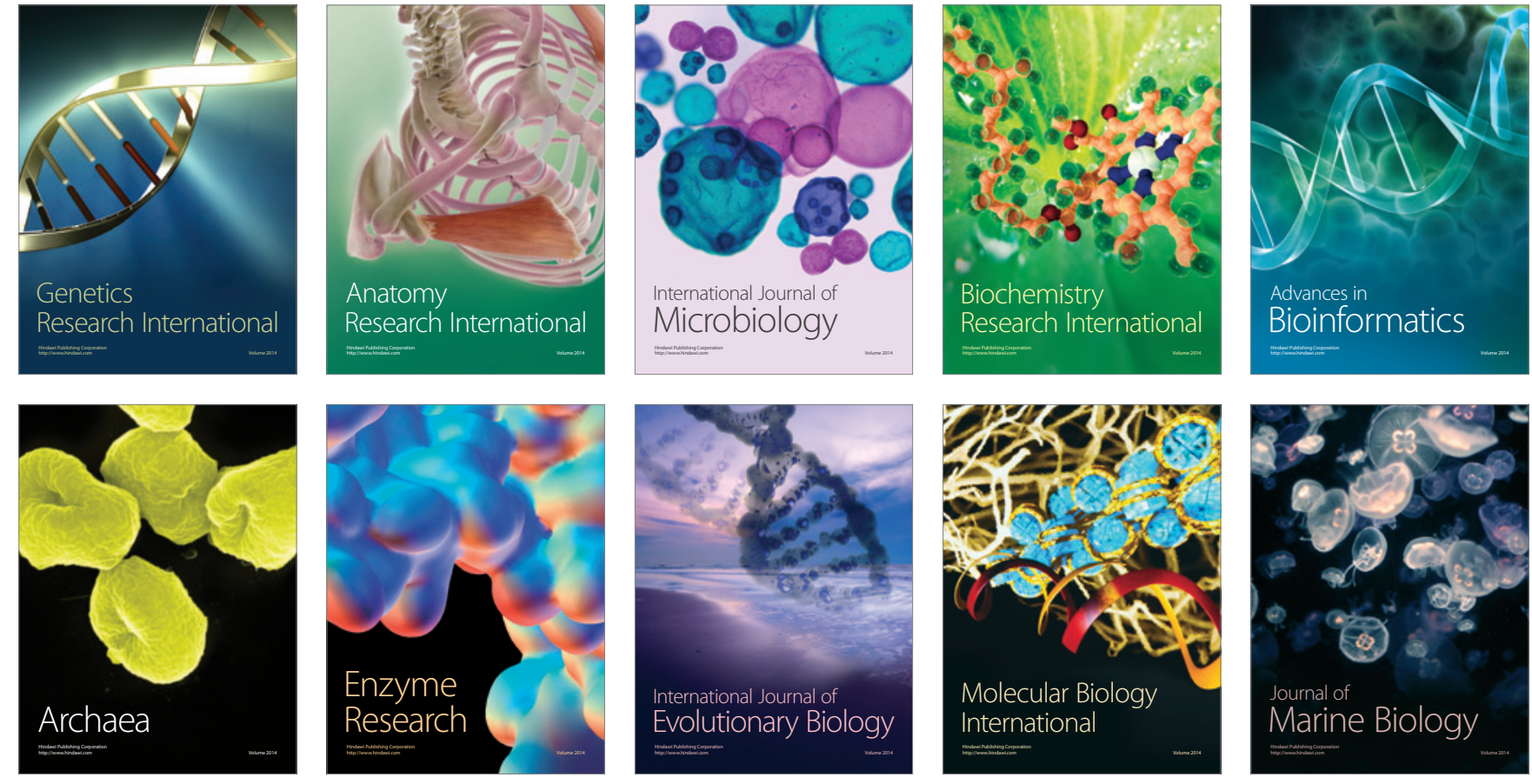